\title{
The obestatin receptor (GPR39) is expressed in human adipose tissue and is down-regulated in obesity-associated type 2 diabetes mellitus
}

\author{
V. Catalán*, J. Gómez-Ambrosi*, F. Rotellar†, C. Silvał, M. J. Gil§, A. Rodríguez*, J. A. \\ Cienfuegos $\dagger$, J. Salvadort and G. Frühbeck*t \\ * Metabolic Research Laboratory, and Departments of $\uparrow$ Surgery, $\$$ Endocrinology and \\ $\S$ Biochemistry, Clínica Universitaria de Navarra, University of Navarra, Pamplona, Spain
}

\section{INTRODUCTION}

\section{Summary}

Objective The G protein-coupled receptor 39 (GPR39) has recently been identified as the receptor for obestatin, a peptidic hormone involved in energy homeostasis. However, the expression levels of this receptor in human adipose tissue in obesity and obesity-associated type 2 diabetes mellitus (T2DM) remain unknown. Therefore, we evaluated the actual presence of GPR39 mRNA in human adipose tissue and whether GPR39 expression levels are altered in obesity and obesity-associated T2DM.

Design Omental adipose tissue biopsies obtained from 15 women were used in the study. Patients were classified as lean (body mass index $20.8 \pm 1.0 \mathrm{~kg} / \mathrm{m}^{2}$ ), obese normoglycaemic (body mass index $48 \cdot 4 \pm 2 \cdot 1 \mathrm{~kg} / \mathrm{m}^{2}$ ) and obese T2DM patients (body mass index $52 \cdot 6 \pm 4.9$ $\mathrm{kg} / \mathrm{m}^{2}$ ). Anthropometric measurements and biochemical profiles were assessed for each subject. Real-time RT-PCR analyses were performed to quantify transcript levels of GPR39 and adiponectin.

Results Obese T2DM patients exhibited significantly lower GPR39 expression levels compared to lean $(P=0.016)$ and obese normoglycaemic subjects $(P=0.008)$, while no differences between lean and obese normoglycaemic patients were observed. The mRNA expression levels of GPR39 were negatively correlated to fasting glucose concentrations $(r=-0.581, P=0.023)$, while exhibiting a positive correlation to adiponectin mRNA expression levels $(r=0 \cdot 674, P=0 \cdot 006)$.

Conclusion GPR39 is expressed in human adipose tissue. The reduced expression levels of GPR39 in omental adipose tissue observed in obese patients with T2DM suggest an involvement of obestatin signalling in glucose homeostasis and T2DM development.

Correspondence: Gema Frühbeck, Department of Endocrinology, Clínica Universitaria de Navarra, University of Navarra, Avda. Pío XII, 36, 31008 Pamplona, Spain. Tel.: +34 948 255400 (ext. 4484); Fax: +34 948 296500; E-mail: gfruhbeck@unav.es 
The $\mathrm{G}$ protein-coupled receptor 39 (GPR39) was isolated from human genomic libraries closely related to the growth hormone secretagogue receptor $(G H S R)$, i.e. the receptor for ghrelin and neurotensin receptor-1. ${ }^{1}$ A highly conserved single-copy gene mapped to human chromosome 2 encodes this receptor and its expression in multiple tissues, including brain and other peripheral organs (such as stomach or intestine), is consistent with a role in energy balance regulation. ${ }^{2}$

The endogenous ligand of GPR39 was unknown until recently, when Zhang et al. ${ }^{3}$ identified obestatin, an appetite- and gastrointestinal motility-suppressing peptide derived from proghrelin. In contrast to ghrelin, which stimulates food intake and obesity in rats, ${ }^{4}$ obestatin appears to act as an anorexic hormone by decreasing food intake, gastric emptying and body weight gain. ${ }^{3}$ These findings support a role for the involvement of obestatin and ghrelin in energy homeostasis. However, the exact contribution of GPR39 needs to be further disentangled. ${ }^{5}$

Obesity is often associated with insulin resistance with type 2 diabetes mellitus (T2DM) being one of the most frequent obesity-associated conditions. It has been proposed that ghrelin and obestatin play a role in the modulation of the release of insulin and glucagon;4,6-8 therefore, representing potential targets for obesity treatment. ${ }^{3}$

To date, the expression of GPR39 in adipose tissue has not been described. Since body fat represents a key peripheral organ in energy balance, the aim of our study was (i) to decipher whether GPR39 is actually expressed in adipose tissue, and (ii) to identify the influence of obesity and obesity-associated T2DM on the expression levels of GPR39.

\section{SUBJECTS AND METHODS}

\section{Experimental subjects}

Fifteen adipose tissue samples obtained from the omental depot of lean and obese women were used in the study. Patients were classified as obese according to both body mass index (BMI $>! 30 \mathrm{~kg} / \mathrm{m}^{2}$ ) and body fat percentage ( $\mathrm{BF}>$ ! 35\%). BMI was calculated as weight in kilograms divided by the square of height in metres and body fat was estimated by air-displacement-plethysmography (Bod$\operatorname{Pod} \AA$, Life Measurements, Concord, CA, USA). To determine the effects of T2DM on gene expression, obese volunteers were further subclassified into two groups according to the presence or not of T2DM (Table 1). All lean and obese normoglycaemic (NG) patients had plasma glucose concentrations below $5.6 \mathrm{mmol} / \mathrm{l}$ after fasting and below $7.8 \mathrm{mmol} / 12 \mathrm{~h}$ after an oral glucose tolerance test (OGTT). T2DM was established on the basis of fasting glucose concentrations $>-7 \cdot 0$ $\mathrm{mmol} / \mathrm{l}$ and glycaemia $>-11.2 \mathrm{mmol} / \mathrm{l} 2 \mathrm{~h}$ after an OGTT. T2DM subjects were not on insulin therapy or on medications likely to influence endogenous insulin levels. The samples were collected from patients undergoing either bariatric surgery or Nissen fundoplication at the Clínica Universitaria de Navarra. Both interventions were carried out via a laparoscopic approach. Tissue samples were immediately frozen in liquid nitrogen and stored at $-80{ }^{\circ} \mathrm{C}$ for gene expression analysis. The study was approved, from an ethical and scientific standpoint, by the hospital's ethical committee responsible for research and the informed consent of participants was obtained. 


\section{Blood assays}

Blood was obtained by venipuncture after an overnight fast. Serum glucose was analysed by an automated analyser (Hitachi Modular P800, Roche, Basel, Switzerland), with quantification being based on enzymatic colorimetric reactions. Serum insulin was measured by means of an enzymeamplified chemiluminescence assay (IMMULITE®, Diagnostic Products Corp., Los Angeles, CA, USA). Total cholesterol and triglyceride concentrations were determined by enzymatic spectrophotometric methods (Boehringer Mannheim, Mannheim, Germany). High-density lipoprotein cholesterol (HDL-C) was quantified by a colorimetric method in a Beckman Synchron ${ }^{\circledR}$ CX analyser (Beckman Instruments, Ltd, Bucks, UK). Low-density lipoprotein (LDL) cholesterol was calculated by the Friedewald formula. Adiponectin was determined using a commercially available ELISA kit (Biovendor, Heilderberg, Germany). Intra- and interassay coefficients of variation were $6.7 \%$ and $7 \cdot 8 \%$, respectively. Leptin was measured by a double-antibody RIA method (Linco Research Inc., St. Charles, MO, USA). Intra- and interassay coefficients of variation were $5 \cdot 0 \%$ and $4 \cdot 5 \%$, respectively.

\section{RNA extraction and real-time PCR}

Adipose tissue RNA isolation was performed by homogenization with an ULTRA-TURRAX ${ }^{\circledR} \mathrm{T}$ 25 basic (IKA ${ }^{\circledR}$ Werke GmbH, Staufen, Germany) using TRIzol ${ }^{\circledR}$ Reagent (Invitrogen, Barcelona, Spain). Samples were purified using the RNeasy Mini kit (Qiagen, Barcelona, Spain) and treated with DNase (RNase-free DNase Set, Qiagen). For first strand cDNA synthesis, constant amounts of $1 \mu \mathrm{g}$ of total RNA were reverse transcribed in a $20-\mu 1$ final volume using random hexamers (Roche) as primers and 200 units of M-MLV reverse transcriptase (Invitrogen) as previously described. ${ }^{9}$

The transcript levels for GPR39 and adiponectin were quantified by real-time RT-PCR (7300 Real Time PCR System, Applied Biosystems, Foster City, CA, USA). Primers and probes were designed using the software Primer Express 1.0 (Applied Biosystems) (Table 2). Probes were designed to hybridize between exons to ensure the detection of the corresponding transcript avoiding genomic DNA amplification. The cDNA was amplified at the following conditions: $95{ }^{\circ} \mathrm{C}$ for $10 \mathrm{~min}$, followed by 45 cycles of $15 \mathrm{~s}$ at $95{ }^{\circ} \mathrm{C}$ and 1 min at $59^{\circ} \mathrm{C}$, using the TaqMan ${ }^{\circledR}$ Universal PCR Master Mix (Applied Biosystems). The primer and probe concentrations for gene amplification were $300 \mathrm{nmol} / 1$ and $200 \mathrm{nmol} / \mathrm{l}$, respectively. All results were normalized to the levels of $18 \mathrm{~S} r R N A$ (Applied Biosystems) and relative quantification was calculated using the $\Delta \Delta \mathrm{Ct}$ formula. Relative mRNA expression was expressed as fold expression over the calibrator sample (average of gene expression corresponding to the lean group). All samples were run in triplicate and the average values were calculated.

\section{Data analysis}

Data are presented as mean \pm standard error of the mean (SEM). Differences between groups were analysed by Kruskal-Wallis tests followed by Mann-Whitney's $U$-tests. Pearson's correlation coefficients $(r)$ were computed to explore the correlation between two variables. The calculations were performed using the SPSS/Windows version 11.0.1 statistical package (SPSS Inc., Chicago, IL, USA). A $P$-value of $<0.05$ was considered statistically significant. 


\section{RESULTS}

The obese NG patients included in our study showed significantly higher body fat (BF), insulin and leptin concentrations, while exhibiting lower HDL-C levels as compared to the lean subjects (Table 1). Obese T2DM patients had significantly $(P<0.05)$ increased glucose concentrations in the fasting state and $2 \mathrm{~h}$ after an OGTT, and significantly reduced $(P<0.05)$ adiponectin levels in comparison to the lean and obese NG volunteers (Table 1). The hypoadiponectinaemia observed in the obese T2DM patients is consistent with the proven beneficial insulin-sensitizing effects of this adipokine. ${ }^{10}$

Real-time PCR analysis indicated that GPR39 is expressed in all samples of adipose tissue, providing evidence, for the first time, of the presence of GPR39 in adipose tissue. Expression levels were significantly lower in obese T2DM patients compared to lean $(P=0.016)$ and obese NG subjects $(P=0.008)$. Interestingly, a trend towards a twofold increase in GPR39 expression was observed in omental adipose tissue of obese NG patients compared to lean individuals (Fig. 1). In addition, expression levels of GPR39 were negatively correlated to fasting glucose concentrations $(r=-0.581, P=0.023)$ and positively correlated to adiponectin mRNA levels in adipose tissue $(r=0.674, P=0.006)$. No statistically significant correlation between adipose tissue GPR39 expression and body weight, BMI or BF was observed. Taken together, these data suggest the participation of GPR39 signalling in glucose homeostasis and T2DM development.

\section{DISCUSSION}

Obestatin, a recently identified peptide derived from the same gene as ghrelin, has been related to energy balance control. ${ }^{3}$ After differential proteolytic modification, the two hormones exert opposing actions on weight regulation through the activation of distinct receptors. For this reason, we analysed the gene expression level of GPR39, the receptor for obestatin, in human adipose tissue samples. In addition, we further gained insight into the influence of obesity and T2DM on the expression of this receptor.

A significant correlation between insulin and obestatin concentrations in the postnatal pancreas has been described previously, raising the possibility that obestatin may play a role in the control of insulin secretioná Several analyses have been carried out exploring the relation between ghrelin and glucose homeostasis, but results are contradictory. It has been reported that ablation of ghrelin contributes to an enhanced glucose-induced insulin secretion, ${ }^{7}$ which is in agreement with data describing that ghrelin administration inhibited glucoseinduced insulin secretion. ${ }^{11}$ In contrast, another study has shown a dual effect of ghrelin with low concentrations inhibiting insulin secretion of mouse pancreatic islets, while high ghrelin levels resulting in insulin stimulation. ${ }^{12}$ In the light of the ghrelin-obestatin antagonism these differences might be attributed to the intricate balance of obestatin and ghrelin in the regulation of energy homeostasis and the difficulties to extract clear-cut conclusions when the preproghrelin gene is removed. ${ }^{5,6}$

GPR39 has shown a high degree of constitutive signalling through the serum response element (SRE) pathway. ${ }^{13}$ A close interaction between phosphatidylinositol 3-kinase (PI3K) and SREmediated transcription has been previously described ${ }^{14}$ with the PI3K pathway being responsible for 
a fraction of SRE activation through GPR39. Furthermore, the PI3K pathway is known to play a critical role in the effects of insulin on glucose metabolism. ${ }^{14}$ Several defects in the insulin signalling pathway such as reduction of $\mathrm{PI}^{3} \mathrm{~K}^{15}$ and Akt kinase ${ }^{16}$ activities have been reported in T2DM patients. Therefore, a reduced expression of GPR39 and, hence, a decreased PI3K activity may contribute to the defective insulin signalling that takes place in adipose tissue of T2DM patients.

In summary, our findings show for the first time that GPR39 mRNA is expressed in adipose tissue and that it is reduced in obese T2DM patients. Moreover, the lack of correlation of GPR39 expression with body weight, BMI and BF together with the significant negative correlation to glycaemia points more towards the involvement of obestatin signalling in glucose homeostasis and T2DM development rather than in body weight control. Determining the effects of circulating obestatin and understanding the signalling pathway activated via its receptor GPR39 will shed more light on the complex neuroendocrine control of energy homeostasis and body weight.

\section{ACKNOWLEDGEMENTS}

This work was supported by grants FIS RGTO G03/028 and FIS PI03/ 0381 from the Instituto de Salud Carlos III, Ministerio de Sanidad y Consumo, Spain, and by the Department of Health of the Gobierno de Navarra (48/2003). The authors gratefully acknowledge the valuable collaboration of the surgery assistant nurses Marisa Acedo, Beatriz Casas, Myriam Fernández and M. Jesús Cordeu.

\section{REFERENCES}

1 McKee, K.K., Tan, C.P., Palyha, O.C., Liu, J., Feighner, S.D., Hreniuk, D.L., Smith, R.G., Howard, A.D. \& Van der Ploeg, L.H. (1997) Cloning and characterization of two human G protein-coupled receptor genes (GPR38 and GPR39) related to the growth hormone secretagogue and neurotensin receptors. Genomics, 46, 426-434.

2 Jackson, V.R., Nothacker, H.P. \& Civelli, O. (2006) GPR39 receptor expression in the mouse brain. Neuroreport, 17, 813-816.

3 Zhang, J.V., Ren, P.G., Avsian-Kretchmer, O., Luo, C.W., Rauch, R., Klein, C. \& Hsueh, A.J. (2005) Obestatin, a peptide encoded by the ghrelin gene, opposes ghrelin's effects on food intake. Science, 310, 996-999.

4 Ghigo, E., Broglio, F., Arvat, E., Maccario, M., Papotti, M. \& Muccioli, G. (2005) Ghrelin: more than a natural GH secretagogue and/or an orexigenic factor. Clinical Endocrinology, 62, $1-17$.

5 Gualillo, O., Lago, F., Casanueva, F.F. \& Diéguez, C. (2006) One ancestor, several peptides post-translational modifications of preproghrelin generate several peptides with antithetical effects. Molecular and Cellular Endocrinology, 256, 1-8.

6 Nogueiras, R. \& Tschöp, M. (2005) Separation of conjoined hormones yields appetite rivals. Science, 310, 985-986. 
7 Sun, Y., Asnicar, M., Saha, P.K., Chan, L. \& Smith, R.G. (2006) Ablation of ghrelin improves the diabetic but not obese phenotype of ob/ob mice. Cell Metabolism, 3, 379-386.

8 Chanoine, J.P., Wong, A.C. \& Barrios, V. (2006) Obestatin, acylated and total ghrelin concentrations in the perinatal rat pancreas. Hormone Research, 66, 81-88.

9 Gómez-Ambrosi, J., Catalán, V., Diez-Caballero, A., Martínez-Cruz, L.A., Gil, M.J., GarcíaFoncillas, J., Cienfuegos, J.A., Salvador, J., Mato, J.M. \& Frühbeck, G. (2004) Gene expression profile of omental adipose tissue in human obesity. FASEB Journal, 18, 215-217.

10 Vilarrasa, N., Vendrell, J., Maravall, J., Broch, M., Estepa, A., Megia, A., Soler, J., Simón, I., Richart, C. \& Gómez, J.M. (2005) Distribution and determinants of adiponectin, resistin and ghrelin in a randomly selected healthy population. Clinical Endocrinology, 63, 329-335.

11 Dezaki, K., Hosoda, H., Kakei, M., Hashiguchi, S., Watanabe, M., Kangawa, K. \& Yada, T. (2004) Endogenous ghrelin in pancreatic islets restricts insulin release by attenuating $\mathrm{Ca}^{2+}$ signaling in â-cells: implication in the glycemic control in rodents. Diabetes, 53, 3142-3151.

12 Salehi, A., Dornonville de la Cour, C., Hakanson, R. \& Lundquist, I. (2004) Effects of ghrelin on insulin and glucagon secretion: a study of isolated pancreatic islets and intact mice. Regulatory Peptides, 118, 143-150.

13 Holst, B., Holliday, N.D., Bach, A., Elling, C.E., Cox, H.M. \& Schwartz, T.W. (2004) Common structural basis for constitutive activity of the ghrelin receptor family. Journal of Biological Chemistry, 279, 53806-53817.

14 Shepherd, P.R., Nave, B.T. \& O'Rahilly, S. (1996) The role of phosphoinositide 3-kinase in insulin signalling. Journal of Molecular Endocrinology, 17, 175-184.

15 Cusi, K., Maezono, K., Osman, A., Pendergrass, M., Patti, M.E., Pratipanawatr, T., DeFronzo, R.A., Kahn, C.R. \& Mandarino, L.J. (2000) Insulin resistance differentially affects the PI 3-kinase- and MAP kinase-mediated signaling in human muscle. Journal of Clinical Investigation, 105, 311-320.

16 Krook, A., Roth, R.A., Jiang, X.J., Zierath, J.R. \& Wallberg-Henriksson, H. (1998) Insulinstimulated Akt kinase activity is reduced in skeletal muscle from NIDDM subjects. Diabetes, 47, $1281-1286$. 
Table 1. Anthropometric and biochemical parameters of lean and obese subjects

\begin{tabular}{|c|c|c|c|}
\hline & Lean $(n=5)$ & $\begin{array}{r}\text { Normoglycaemic } \\
\text { obese }(n=5)\end{array}$ & T2DM obese $(n=5)$ \\
\hline Age (years) & $38 \pm 4$ & $36 \pm 5$ & $43 \pm 3$ \\
\hline BMI $\left(\mathrm{kg} / \mathrm{m}^{2}\right)$ & $20 \cdot 8 \pm 1 \cdot 0$ & $48 \cdot 4 \pm 2 \cdot 1^{*}$ & $52 \cdot 6 \pm 4 \cdot 9 *$ \\
\hline Body fat $(\%)$ & $28 \cdot 7 \pm 3 \cdot 0$ & $56 \cdot 3 \pm 1 \cdot 1^{*}$ & $54 \cdot 0 \pm 1 \cdot 8^{*}$ \\
\hline $\begin{array}{l}\text { Fasting glucose }(\mathrm{mg} / \mathrm{dl}) \times 0.056 \\
=\mathrm{mmol} / 1\end{array}$ & $5 \cdot 1 \pm 0 \cdot 2$ & $4 \cdot 9 \pm 0 \cdot 3$ & $7 \cdot 6 \pm 0.6 * \dagger$ \\
\hline $\begin{array}{l}2 \mathrm{~h} \text { OGTT glucose }(\mathrm{mg} / \mathrm{dl}) \mathrm{x} \\
0 \cdot 056=\mathrm{mmol} / 1\end{array}$ & $6 \cdot 0 \pm 0 \cdot 6$ & $6 \cdot 4 \pm 0 \cdot 3$ & $14 \cdot 7 \pm 2 \cdot 4 * \dagger$ \\
\hline $\begin{array}{l}\text { Fasting insulin }(\mu \mathrm{U} / \mathrm{ml}) \times 7 \cdot 18 \\
=\mathrm{mmol} / 1\end{array}$ & $53 \cdot 1 \pm 11 \cdot 5$ & $129 \cdot 2 \pm 33 \cdot 7 *$ & $162 \cdot 3 \pm 45 \cdot 9 *$ \\
\hline $\begin{array}{l}2 \mathrm{~h} \text { OGTT insulin }(\mu \mathrm{U} / \mathrm{ml}) \mathrm{x} \\
7 \cdot 18=\mathrm{mmol} / \mathrm{l}\end{array}$ & $75 \cdot 4 \pm 12$ & $740 \cdot 3 \pm 307 \cdot 3 *$ & $651 \pm 133 \cdot 5^{*}$ \\
\hline $\begin{array}{l}\text { Triglycerides }(\mathrm{mg} / \mathrm{dl}) \times 0.0113= \\
\mathrm{mmol} / \mathrm{l}\end{array}$ & $0 \cdot 86 \pm 0 \cdot 1$ & $1 \cdot 2 \pm 0 \cdot 1$ & $1 \cdot 5 \pm 0 \cdot 2$ \\
\hline $\begin{array}{l}\text { Total cholesterol }(\mathrm{mg} / \mathrm{dl}) \times 0.026 \\
=\mathrm{mmol} / 1\end{array}$ & $4 \cdot 8 \pm 0 \cdot 3$ & $4 \cdot 8 \pm 0 \cdot 4$ & $5 \cdot 2 \pm 0 \cdot 3$ \\
\hline $\begin{array}{l}\text { HDL cholesterol }(\mathrm{mg} / \mathrm{dl}) \times \\
0 \cdot 02586=\mathrm{mmol} / \mathrm{l}\end{array}$ & $1 \cdot 4 \pm 0 \cdot 1$ & $0 \cdot 98 \pm 0 \cdot 1 *$ & $0 \cdot 99 \pm 0 \cdot 1 *$ \\
\hline LDL cholesterol (mg/dl) & $3 \cdot 7 \pm 0 \cdot 2$ & $3 \cdot 8 \pm 0 \cdot 3$ & $4 \cdot 1 \pm 0 \cdot 2$ \\
\hline Leptin (ng/ml) & $9 \cdot 1 \pm 1 \cdot 7$ & $57 \cdot 6 \pm 7 \cdot 6^{*}$ & $69 \cdot 4 \pm 19 \cdot 6^{*}$ \\
\hline Adiponectin $(\mu \mathrm{g} / \mathrm{ml})$ & $11 \cdot 2 \pm 2 \cdot 4$ & $8 \cdot 8 \pm 0 \cdot 8$ & $4 \cdot 8 \pm 0 \cdot 5 * \dagger$ \\
\hline
\end{tabular}

Data are mean \pm standard error of the mean. Differences between both groups were by Kruskal-Wallis followed by Mann-Whitney's $U$-tests. ${ }^{*} P<0.05$ vs. lean. $\dagger P<0.05$ vs. normoglycaemic obese. BMI, body mass index; HDL, high-density lipoprotein; LDL, low-density lipoprotein; OGTT, oral glucose tolerance test; T2DM, type 2 diabetes mellitus. 
Table 2. Sequences of the primers and TaqMan probes

\begin{tabular}{c|l}
\hline Gene (GenBank accession) & Oligonucleotide sequence $\left(5^{\prime}-3^{\prime}\right)$ \\
\hline GPR39 (NM_001508) & \\
Forward & TTCCTGAGGCTGATTGTTGTGA \\
Reverse & GCCATGATCCTCCGAATCTG \\
Probe & FAM-ATTGGCCGTATGCTGGATGCCCA-TAMRA \\
\hline ADIPOQ (NM_004797) & \\
Forward & GGAGATCCAGGTCTTATTGGTCCTA \\
Reverse & CCTTGGATTCCCGGAAAGC \\
Probe & FAM-ACATCGGTGAAACCGGAGTACCCGG-TAMRA \\
\hline
\end{tabular}




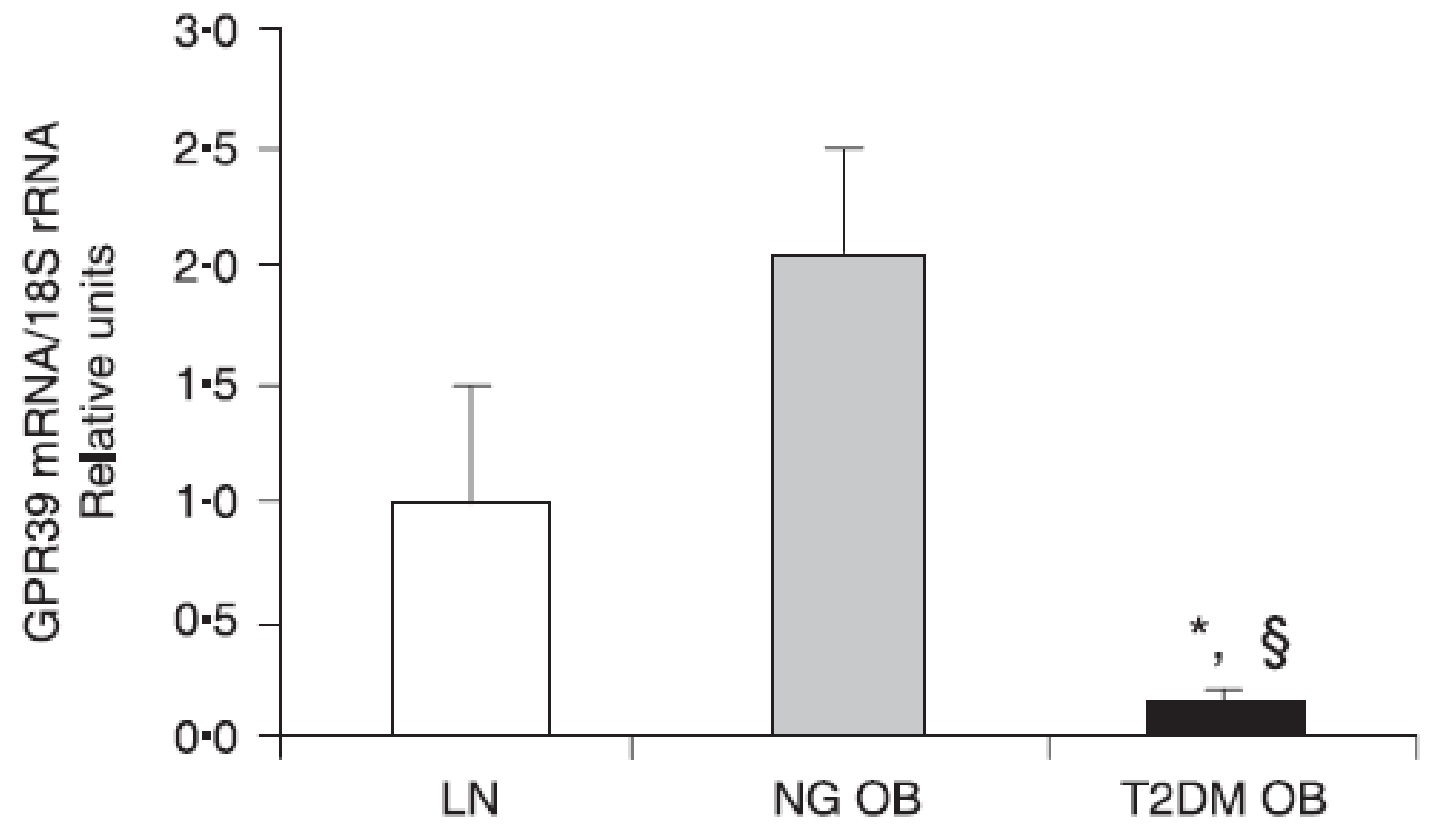

Fig. 1 Real-time RT-PCR analysis of GPR39 transcript levels in omental adipose tissue of lean (LN), normoglycaemic obese (NG OB) and diabetic obese (T2DM OB) volunteers ( $n=5$ per group). Bars represent the mean \pm SEM of the ratio between GPR39-18S rRNA. The expression of GPR39 in lean subjects was assumed to be 1 . Differences between groups were analysed by Kruskal-Wallis followed by Mann-Whitney $U$-tests. ${ }^{*} P<0.05$ vs. LN. $\S P<0.05$ vs. NG OB. 